\title{
POSITION
}

\section{ANTROPOLOGER HAR DATA}

\section{LISE RØJSKJÆER PEDERSEN}

Jeg har indtil for nylig tænkt, at „data“ er noget, antropologer producerer, indsamler, skaber og dermed „har" eller i hvert fald „făr“. Data er både de observationer, vi skriver ned i feltbøger, såvel som det er interviews, citater, indtryk, billeder osv., som vi indhenter gennem de relationer, vi indgår i under feltarbejde. Data er en fællesbetegnelse for alt det, vi skal bruge til at lave analyser, narrativer og argumenter. Men for nylig stødte jeg på det modsatte udsagn i en diskussion om en antropologisk antologi, som handler om, at den verden, vi lever i lige nu, er „datamættet“ (Knox \& Nafus 2018). Det vil sige, at der er data alle vegne. Data er på alles læber i disse år, data betragtes af store dele af forretningsverdenen og af de offentlige myndigheder som den nye olie, det nye råstof, det nye guld, der kan udvindes og udnyttes i uudtømmelige mængder. Under diskussionen stillede en kollega spørgsmålet: „Har antropologer data?“ Da jeg spurgte til, hvad antropologer har, hvis de ikke har data, svarede min kollega, at de har „ting“ og „materialer“.

I denne position undersøger jeg udsagnet, ,antropologer har ikke data“ $\mathrm{i}$ et forsøg på at pege på nogle af de udfordringer og dilemmaer, der kan være, når vi studerer felter, der overlapper eller er i konflikt med vores eget metodiske apparat. Hvad sker der, når det, vi gør (producerer data), og det, vi studerer (produktionen af data i en datatidsalder), kollapser? Så føler vi os trængte og ønsker at flytte os og begive os andre steder hen, prøve nye begreber af, så vi igen kan producere den sikre afstand, der gør feltarbejde, objektivering og analyse mulig. Men hvad ville der ske, hvis vi ikke flyttede os og i stedet insisterede på, at antropologer producerer og „har“ data? Måske ikke den samme slags data som andre discipliner, som teknologivirksomheder eller offentlige myndigheder og langtfra frembragt på samme måde, men dog alligevel data ...? Hvilke muligheder ville det for eksempel åbne i forhold til at indgå i og influere de aktuelle debatter om, hvad data er, og hvad de skal bruges til? Og hvilke berøringsflader og 
samarbejdsplatforme med andre aktører, der arbejder med data, ville det kunne synliggøre? Hvilke nye typer data og datametoder ville vi kunne blive medudviklere af i sådanne samarbejder?

\section{Data, data, data ...}

Ordet „data“ kommer oprindeligt fra det latinske ord „datum“, som betyder „det, der er givet“. Inden for matematikkens og filosofiens verdener er begrebet „data“ blevet brugt som betegnelse for den kategori af fænomener i verden, der er hinsides enhver form for debat og tvivl. I denne optik udgøres „data“ af de fundamentelle principper, som analyser og hypoteser kan udledes på baggrund af (Gregg 2015).

I projektet „Data as Relation“, som er forankret på ITU, forsker jeg i såkaldt „datadrevet ledelse“ $i$ den offentlige sektor. Det vil konkret sige, at jeg kigger på kommunale lederes forståelse af og forestillinger om data og på deres eksperimenter med at gøre data til en type ledelsesinformation, altså til en form for beslutningsgrundlag, som de kan styre kommunen ud fra. Der er ingen tvivl om, at hypen omkring big data, machine learning og algoritmer har ramt de danske kommuner.

Selvom man i årtier har indsamlet data om borgerne i registre og optegnelser, ikke mindst i forbindelse med CPR-nummeret, og således har arbejdet med data som en del af offentlig ledelse i mange år, betragtes „det datadrevne“ af mange alligevel som et paradigmeskift. Skiftet synes på den ene side at bero på en forventning om, at der er kommet og vil komme meget mere data, særligt nye typer af digital data, i takt med den globale digitalisering, teknologiernes generelle udvikling og ikke mindst den øgede forbundethed mellem diverse teknologier, devices og datasæt. Forestillingen om „det datadrevne samfund“ handler om stadig mere dugfriske og frie data, der kan flyttes rundt, krydses og kombineres $\mathrm{i}$ uudtømmelige kombinationer (Bell 2015), som et perfekt data-tag-selv-bord. På den anden side hviler dette paradigmeskift på en myte om, at mere data er lig med større sandhed; jo flere data, der indsamles og gøres til foder for algoritmen, desto tættere kommer vi på sandheden, og desto mindre har vi brug for menneskelige fortolkninger og teorier (Anderson 2008).

Under min ph.d.-forskning stødte jeg på en anden forståelse af data. I knap et år studerede jeg konsulenter, der producerer og sælger det, de kalder „etnografiske data" til kommercielle formål. De laver feltarbejde og producerer kvalitative data, som de analyserer ved hjælp af klassiske samfundsvidenskabelige greb som komparation, kontekstualisering og generalisering. En central del af konsulenternes metode er at involvere kunden $i$ arbejdet med at analysere 
og fremstille indsigter ud fra de indsamlede data. Det vil altså sige, at snarere end at servere facts eller konklusioner for kunderne i slutningen af et konsulentprojekt skal kunden opleve dataanalysen og processen (dog på en nøje tilrettelagt og æstetisk forførende måde). Selvom konsulenterne selv opfattede de data, de indsamlede, som neutrale sandheder om forskellige menneskelige verdener, havde de et kæmpe metodisk apparat, som foruden intensive kurser i spørgeteknikker indebar præfabrikerede skabeloner til notetagning og stramme guidelines for øvelser, spørgsmål, fotografering m.m. Indsamlingen af data var altså nøje planlagt og orkestreret til at opfylde helt bestemte mål, nemlig i sidste ende at gøre en kunde tilfreds.

Og hvad er så pointen med at fremhæve de her to forståelser af data? Begge udspringer tilsyneladende af en klassik positivistisk tilgang til viden og data som skitseret $\mathrm{i}$ ordets etymologiske oprindelse, nemlig, at vi kan gå ud i verden og finde noget, der er neutralt og objektivt, frit for menneskelig kontaminering. I diskursen om „det datadrevne“, der primært handler om digitale store data (big data), er den menneskelige og fortolkende dimension i frembringelsen af data mindre tydelig end i konsulenternes verden, der er baseret i etnografien. Det interessante ved konsulenterne er imidlertid deres arbejde med at forsøge at gøre etnografiske data utvetydige (,hårde“) ved at bruge skabeloner og oversættelsesteknikker, næsten som i laboratoriearbejde (Latour 1999). De eksperimenterer med at krydse forskellige videnskabelige paradigmer og discipliner (eksempelvis naturvidenskab og humaniora) i et forsøg på at påvirke forretningsverdenen med andre former for data end tal og statistikker. De fortæller historier fra feltarbejde, beskriver cases og fremhæver eksempler, som vi kender det fra antropologien, men i nøje konstruerede kausalitetskæder, der tjener til at appellere til kundernes vanlige factorienterede måde at ræsonnere på.

Min intention med at fremhæve disse ovenstående datauniverser er at stille to kritiske spørgsmål til antropologiens omgang med begrebet „data“: Hvordan kan vi bruge indsigter fra forskellige datauniverser til at belyse og udvide den antropologiske (selv)forståelse af data og datafrembringelse samt til at forstå antropologiens effekt og rolle uden de akademiske skyklapper? Og hvordan kan vi bruge de forskelle og overlap, vi kan konstatere, der er mellem big data, etnografiske konsulentdata og den akademiske, performative tilgang til data, til at nuancere, problematisere og især ,jordforbinde“ det aktuelle, globale big data-storhedsvanvid?

\section{Udvandede data og mellemregningernes evidens}

Tilbage til min kollegas tøven og forbehold over for at kalde det, antropologer har eller producerer, for data. Spørgsmålet er, hvad begrebet „data“ gør ved el- 
ler for antropologien i en datamættet tidsalder. Kigger vi tilbage i faghistorien, kan vi identificere $\mathrm{i}$ hvert fald to andre tidspunkter, hvor populære kalibreringer og anvendelser af antropologiske fagtermer har givet anledning til stor debat og selvransagelse i antropologien. Disse to er kulturbegrebets udbredelse (eller udvanding) op igennem 1980'erne og lidt senere boomet $i$ anvendelsen af „etnografi“ inden for især design, marketing og konsulentbranchen. Kalder den aktuelle, globale dataficering og datahype ligeledes på en gentænkning af begrebet „data“, en gentænkning af, hvad det er, vi antropologer producerer og har? Hvor kulturdebatterne fordrede en refleksion over forskningsobjektet, repræsentationsformer og de politiske effekter af vores repræsentationer, og hvor etnografiens kommercielle popularitet satte gang i diskussioner om vores felt- og analysemetoder, skaber „big data“ og GDPR-tidsalderen nu en ny bølge af refleksion over den antropologiske praksis, en refleksion, der centrerer sig om den slags „stof“, vi skaber og har. Hvordan eller hvornår bliver noget til antropologiske eller etnografiske data? For spørgsmålet er vel, om begrebet „data“ i dag er så ladet og politiseret, at vi som antropologer ikke kan, bør eller skal bruge det om det, vi skaber i vores videnskabelige arbejde? Eller rummer denne tid netop en mulighed for at sætte en slags kile ind i debatterne med beskrivelser af, hvordan data bliver til på baggrund af bestemte intentioner og formål og i bestemte kontekster, og at de således aldrig er neutrale eller objektive?

Kirsten Hastrup beskriver, hvordan antropologiens vej til evidens i højere grad end mange andre discipliner ligger i den måde, hvorpå vi fremlægger vores metodiske og analytiske mellemregninger (Hastrup 2004). I den antropologiske disciplin trænes vi generelt til at være eksplicitte i forhold til spørgsmål om, hvorfor vi forbinder bestemte eksempler og situationer og ophæver dem til at have forklaringskraft. Netop dette fokus på mellemregningerne forskyder ifølge Hastrup evidensproblematikken fra det ontologiske til det epistemologiske. Det antropologiske feltarbejde afslører, at der altid er et overskud af begivenheder, situationer, tanker og handlinger, som kunne have været inddraget i en given analyse og fortolkning, og som således ,udgør muligheder for modstand“ (op.cit.461). Men mellemregninger er i mange naturvidenskabelige og teknologiske datapraksisser ikke nødvendigvis noget, der er til forhandling og genbesøg. I tal- og statistikdisciplinerne synes det objektive på en eller anden måde ikke at give anledning til samme form for selvransagelse og relativering, som i de humanistiske discipliner. Men hvordan forholder det sig med evidens i forhold til big data? Sarah Pink og Deborah Lanzeni taler om big datas mangel på ansvarlighed. Denne mangel, argumenterer de for, hænger sammen med en gennemgående dekontekstualisering af de data, der fremstilles. Big data er ofte løsrevet fra konteksten, de steder, situationer og meninger, som de oprindeligt refererede til, for at indgå i nye kontekster (Pink \& Lanzeni 2018:3). 
Det, vi kan udlede fra de ovenstående beskrivelser af den antropologiske og big data-orienterede omgang med data og evidens, er med Hastrups ord, at måden, vi tilegner os viden og skaber data på, i den grad påvirker, hvad der kan betragtes som valid og relevant viden (Hastrup 2004:462). Når vi sammenholder de her forskellige dataforståelser med et fokus på mellemregninger og kontekst, bliver det tydeligt, at en af de store forskelle mellem de præsenterede dataparadigmer ligger i subjekt-objekt-relationen, i relationen mellem det indsamlede og den eller det, der indsamler. Når vi taler big data, er subjektet - den/det indsamlende organ - ofte ikke synligt eller rettere, det er uklart, hvem eller hvad der står bag frembringelsen af data, og dermed bliver mellemregningerne også utydelige. Når vi derimod taler datafrembringelse i både akademisk antropologi og i erhvervsantropologiske konsulenters arbejde, er mellemregningerne centrale for at opnå status af evidens.

\section{Samarbejde og produktiv modstand}

Lad mig afslutningsvis vende tilbage til mit spørgsmål om, hvad udfordringen ved at studere felter og begreber, der overlapper med antropologiske og videnskabelige begreber såsom „data“, potentielt kan give af nye indsigter. Nyere strømninger inden for antropologien, blandt andet ,paraetnografien“ (Marcus \& Holmes 2008) og ,lateral etnografi““ (Maurer 2005), eksperimenter netop med at sidestille den antropologiske autoritet med andre eksperter i og omkring den udpegede felt. Det vil sige, at der åbnes for, at informanten i lige så høj grad som researcheren er analytiker og teoretiker og dermed medskaber af de analytiske pointer. Analyse er en form for samarbejde og en gensidig modifikation af begreber og praksisser. I min optik er en sådan attitude til antropologisk arbejde helt nødvendig af både politiske, etiske og pragmatiske årsager. Kritisk selvrefleksion og samarbejde på tværs af discipliner og ekspertiser er nøgleord her. Som antropologer skal og bør vi blive bedre til at åbne for modstand og modsvar fra informanter og andre samarbejdspartnere, der har andre typer mellemregninger og måder at ræsonnere og performe viden på end vores antropologiske. Når vi taler kunstig intelligens og algoritmer, bliver det for eksempel særligt tydeligt, at der er brug for at tænke sammen med dem, der kender algoritmens mellemregninger. For måske står vi med disse nye teknologier ved grænsen for, hvad antropologien kan undersøge med den baggage af metode og teori, som faget indtil nu har udviklet.

Med antropologiens tradition for at fremlægge og eksplicitere sit metodiske apparat og vejen fra data til indsigt ligger der en mulighed for at intervenere i de aktuelle debatter og eksperimentere med brugen af data både i den private og offentlige sektor. Hvis relationen mellem data og data producent i big 
data-tidsalderen er blevet sværere at få øje på, herunder de værdier, intentioner og etiske fordringer, der ligger til grund for dem, fordi data til stadighed produceres live og i mange tilfælde, uden at vi tænker over det, kan det antropologiske fokus på mellemregninger, kontekst, etik og relationer være med til at synliggøre, at der også i maskinelt producerede data går en fortolkningsramme og en fortolker forud for tilvejebringelsen af data. Et andet sigte med at holde fast $i$,data"begrebet er selvrefleksion og en gentænkning af antropologiens rolle i samfundet $\mathrm{i}$ bredere forstand, nemlig at antropologers arbejde tages i brug i diverse politiske og strategiske argumenter. Selvom vi fremlægger mellemregninger og gør relationen mellem dataindsamler og data så tydelig, vi kan, i skriverier og andre steder, er vores arbejde også genstand for dataficering og for dekontekstualisering i sammenhænge, vi måske ikke ønsker. Også antropologiske og etnografiske data bliver brugt politisk; det er data, der er gode at lave argumenter med og at fortælle historier med, og de kan få stor magt, når de dekontekstualiseres og fastfryses som fakta.

At kalde noget for „data“ er i dag endnu mindre neutralt, end det har været før, og kan ses som en bestemt form for legitimeringsarbejde, der hviler på visse normer og ideer om objektivitet, fakta og sandhed - sådan som min kollega indledningsvis påpegede i diskussionen om, hvorvidt data er noget, antropologer har. Spørgsmålet er, om vi så skal undlade at bruge begrebet. Et andet spørgsmål er, om det ikke også er en bestemt form for (moralsk) legitimeringsarbejde at undlade at kategorisere det antropologiske arbejde som noget, der har med data at gøre. Hvad vil det sige at arbejde med „materiale“ frem for „data“? Hvilken form for position skaber vi for os selv ved at benævne det, vi gør, som „data“ eller ,ikke-data“? Min position er, at der ligger en mulighed netop i denne tid for at holde fast i, at antropologer er dataproducenter, at antropologer har data. Formålet med at holde fast i ,data“ er dels at tilskynde til faglig selvrefleksion, særligt omkring den antropologiske måde at skabe mellemregninger og evidens på, og dels er det at gøre opmærksom på muligheden for at legitimere antropologien og gøre den relevant på nye måder ved at indgå i debatter og samarbejdsrelationer med nogle af de mange andre dataeksperter, datapraktikere og dataperformere, der befolker de datamættede samfund. 


\section{Litteratur}

Anderson, Chris

2008 The End of Theory. The Data Deluge Makes the Scientific Method Obsolete.

Wired 23. juni. https://www.wired.com/2008/06/pb-theory/.

Bell, Genevieve

2015 The Secret Life of Big Data. In: T. Boellstorff \& B. Maurer (eds): Data, Now Bigger and Better! Pp. 7-26. Chicago: Prickly Paradigm.

Gregg, Melissa

2015 The Gift that Is Not Given. In: T. Boellstorff \& B. Maurer (eds): Data, Now Bigger and Better! Pp. 47-66. Chicago: Prickly Paradigm.

Hastrup, Kirsten

2004 Getting it Right. Knowledge and Evidence in Anthropology. Anthropological Theory 4(4):455-72.

Holmes, Douglas \& George Marcus

2008 Collaboration Today and the Re-Imagination of the Classic Scene of Fieldwork Encounter. Collaborative Anthropologies 1:81-101.

Knox, Hannah \& Dawn Nafus (eds)

2018 Ethnography for a Data-Saturated world. Manchester: Manchester University Press.

Latour, Bruno

1999 Pandora's Hope. Essays on the Reality of Science Studies. Cambridge, MA, \& London: Harvard University Press.

Maurer, Bill

2005 Mutual Life, Limited. Islamic Banking, Alternative Currencies, Lateral Reason. Princeton: Princeton University Press.

Pink, Sarah \& Debora Lanzeni

2018 Future Anthropology Ethics and Datafication. Temporality and the Responsibility in Research. Social Media and Society 4(2):1-9. 
